\title{
Superimposed ice formation and surface energy fluxes on sea ice during the spring melt-freeze period in the Baltic Sea
}

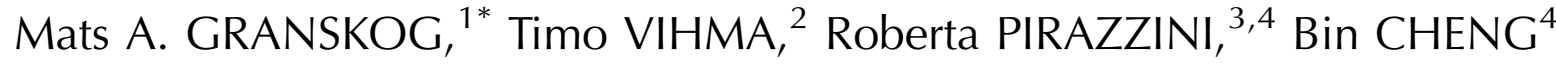 \\ ${ }^{1}$ Arctic Centre, University of Lapland, PO Box 122, FIN-96101 Rovaniemi, Finland \\ E-mail: mgransko@ulapland.fi \\ ${ }^{2}$ Finnish Meteorological Institute, PO Box 503, FIN-00101 Helsinki, Finland \\ ${ }^{3}$ Department of Physical Sciences, PO Box 64, University of Helsinki, FIN-00014 Helsinki, Finland \\ ${ }^{4}$ Finnish Institute of Marine Research, PO Box 2, FIN-00561 Helsinki, Finland
}

\begin{abstract}
The development of land-fast sea ice and overlying snow was monitored during a 4 week period, until the snow cover had completely disappeared, at a site in the Gulf of Bothnia, Baltic Sea $\left(63.57^{\circ} \mathrm{N}, 19.85^{\circ} \mathrm{E}\right)$. The meteorological and radiative boundary conditions were continuously recorded. During the observation period, a $15 \mathrm{~cm}$ thick snow layer on the ice was transformed into a $7 \mathrm{~cm}$ thick granular ice layer (superimposed ice) on the ice surface, contributing significantly (about $11 \%$ ) to the total ice thickness. Approximately $1 \mathrm{~cm}$ w.e. of the snow was sublimated. Neither snow-ice formation nor basal ice growth was significant during the same period. The salinity and isotopic $\left(\delta^{18} \mathrm{O}\right)$ composition of the ice indicated that prior to the experiment a $7 \mathrm{~cm}$ layer of superimposed ice had already formed. Hence, superimposed ice layers contributed $22 \%$ of the total ice thickness by the time all snow had disappeared. The advancing spring, decrease in surface albedo, diurnal cycle in the incoming solar radiation, and synoptic-scale changes in the cloud cover and the air-ice turbulent heat fluxes caused variations in the heat budget of the snowpack. Superimposed ice formation due to refreezing of meltwater occurred during most nights of the study period, and the most important refreezing periods were under such synoptic conditions that the air and snow surface temperatures also remained below zero during daytime. In contrast to typical summer conditions in polar oceans, low snow surface temperatures acted as the primary heat sink for the refreezing of meltwater.
\end{abstract}

\section{INTRODUCTION}

Sea ice and its snow cover are important elements in the climate system. Due to its insulating effect and radiative properties, a snow cover on sea ice strongly modifies the surface energy balance. The snow cover may also be transformed into meteoric ice, either as snow ice or as superimposed ice. The former results from freezing of slush at the snow-ice interface caused by flooding. It requires a negative ice freeboard, which results from a heavy snow load. Superimposed ice forms when snow meltwater or rain accumulates and refreezes at the snow-ice interface (e.g. Kawamura and others, 2001). Via these transformation processes, the snow cover contributes to the sea-ice mass. Meteoric ice also affects the sea-ice heat budget, provides a mechanically strong layer that may extend the lifetime of the sea ice, and increases the light transmission through sea ice by transforming a light-scattering snow layer into a better transmitting ice layer (Haas and others, 2001). The contribution of meteoric ice to the sea-ice mass is substantial, particularly in the Antarctic (Kawamura and others, 1997, 2004; Haas and others, 2001; Jeffries and others, 2001) and the Baltic Sea (Kawamura and others, 2001; Cheng and others, 2003; Granskog and others, 2003a, 2004). In the Arctic, superimposed ice formation takes place (Onstott and others, 1987; Nicolaus and others, 2003), but snow-ice formation is often prevented by the thick ice cover. In light of

*Present address: Centre for Earth Observation Science, Department of Environment and Geography, 114 Isbister Building, University of Manitoba, Winnipeg, Manitoba R3T 2N2, Canada. climate-change scenarios of thinning ice and increasing precipitation (Alexander and others, 2004; Bengtsson and others, 2004), superimposed ice formation may become increasingly important, and snow-ice formation may also become more common in the Arctic.

In the Baltic Sea, depending on the season and year, meteoric ice may contribute up to half of the total ice thickness and up to $35 \%$ of the total mass of land-fast sea ice (Palosuo, 1963; Kawamura and others, 2001; Granskog and others, 2003a, 2004). Superimposed ice layers can grow at least $10-15 \mathrm{~cm}$ thick. The relatively mild and wet climate conditions at the Baltic Sea latitudes, at the southern fringes of the Northern Hemisphere seasonal sea-ice zone, favor the formation of relatively thick superimposed ice layers.

The evolution of snow surface temperature is controlled by turbulent, radiative and conductive heat fluxes. In the Baltic Sea, the snow surface temperature may rise to the melting point even in mid-winter, if advection of warm air and clouds from the south or west results in above-zero near-surface air temperatures. In such cases, snowmelt is caused by the concurrent effects of the downward longwave radiation from clouds and the turbulent heat flux from air to snow. In addition, the net solar radiation makes a small contribution to the net radiation in winter, and it may cause melting when the air temperature is close to zero. In spring, solar radiation becomes increasingly important for snowmelt, especially when the snow albedo decreases and cloud radiative forcing becomes negative. In the Baltic Sea Experiment (BALTEX), a continental-scale experiment under the Global Energy and Water Cycle Experiment (GEWEX), detailed observations of the turbulent and radiative surface fluxes over the ice-covered Baltic Sea for periods of 


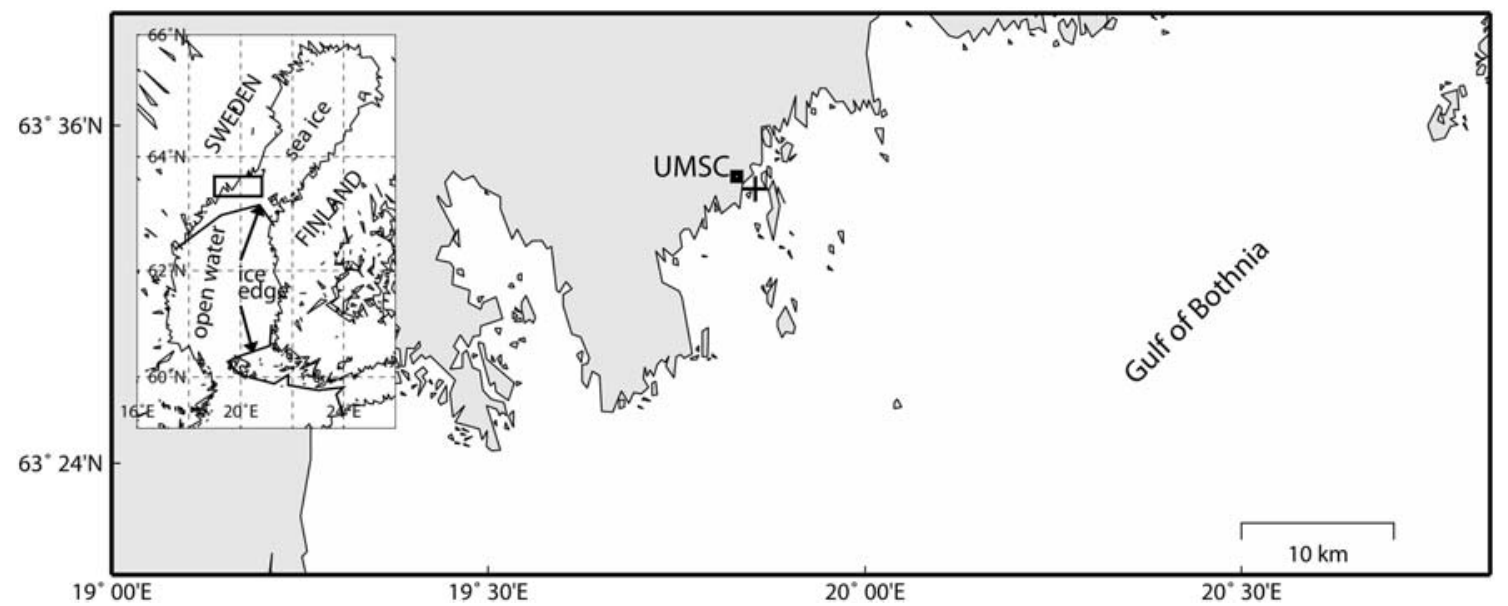

Fig. 1. Map of the study area, with the location of the measurement site (cross), the Umeå Marine Sciences Center (UMSC), and the ice edge location (solid lines) in late March 2004 taken from ice charts.

12-20 days have been made in winter, February-March (Brümmer and others, 2002a, b), but not through the spring melt period. Such observations are essential to better understand the boundary conditions for superimposed ice formation, and could also be used to validate and further develop thermodynamic sea-ice models (Cheng and others, in press). We therefore undertook a study to follow the evolution of the snow/ice system and the surface fluxes during the spring period from the onset until the end of snowmelt.

\section{OBSERVATIONS}

\subsection{Direct observations}

Glaciological and meteorological observations were undertaken on initially $0.55 \mathrm{~m}$ thick land-fast sea ice in the Gulf of Bothnia, Baltic Sea, in the vicinity of the Umeå Marine Sciences Center (UMSC; $63.57^{\circ} \mathrm{N}, 19.85^{\circ} \mathrm{E}$ ) (Fig. 1) during the 4 week period from 16 March (day of year 76) to 10 April (day 101) 2004. The site was chosen because the ice is anchored between the coast and the outlying islands, and the instrument set-up was therefore safe. The site was visited daily.

Two major sampling strategies were used. First, at about $1-3$ day intervals three ice cores were collected (days 80, 82, $83,88,90,92,94,97$ and 99), within a $10 \mathrm{~m} \times 10 \mathrm{~m}$ area, and used to measure the thickness of the surface granular layer using thin sections between crossed polarizers; the method is described in detail by Granskog and others (2003a). The uppermost $20 \mathrm{~cm}$ of the cores were used for crystal structure analysis, after the initial analysis revealed a 6-7 cm thick granular layer at the surface. Second, at weekly intervals (days 79, 86, 93 and 101) ten ice cores with a horizontal spacing of $1 \mathrm{~m}$ were collected along a representative line. Consecutive horizontal lines were spaced $1 \mathrm{~m}$ apart. Along each line, snow and ice thickness and ice freeboard were recorded. The crystal structure of the topmost $20 \mathrm{~cm}$ of these ice cores was recorded on days 86,93 and 101. The upward growth of the ice at the surface was estimated from observations of the changes in the surface granular layer (Nicolaus and others, 2003).

Snow density, stratigraphy and temperature observations were conducted generally every second day, often several times per day, in snow pits in an area devoted to snow observation next to the ice-sampling area. Snow thickness was measured with a ruler. Snow density was measured (whenever possible) at $3 \mathrm{~cm}$ vertical resolution by weighing a defined volume of snow, and temperature profiles were obtained from measurements made at $2 \mathrm{~cm}$ intervals with a hand-held temperature probe (Testo 720).

Samples for $\delta^{18} \mathrm{O}$ determination were taken (days 78, 80, $81,83,86,88,92,93,94,97,99$ and 101) from precipitation and/or from the snowpack and/or from selected ice cores and sea water. $\delta^{18} \mathrm{O}$ was determined using a Finnigan MAT Delta Plus XL mass spectrometer (for details see Granskog and others, 2005). The isotopic composition was used to examine the origin of the surface granular ice layer using the methods outlined in Granskog and others (2003a, 2004). Under-ice water salinity (reported as practical salinity units (psu)) was measured at irregular intervals using a salinometer (WTW LF196; personal communication from M. Steffens, 2005).

For continuous observations of meteorological and radiative boundary conditions, a meteorological station was installed $50 \mathrm{~m}$ south of the sampling area. Air temperature $\left(T_{\mathrm{a}}\right)$ and relative humidity, as well as wind speed $(V)$ and direction at $2 \mathrm{~m}$ height, were obtained at $1 \mathrm{~min}$ intervals. The measurement accuracy was $\pm 0.5 \mathrm{~m} \mathrm{~s}^{-1}$ for wind speed, $\pm 5^{\circ}$ for wind direction, $\pm 5 \%$ for air relative humidity and $\pm 0.1^{\circ} \mathrm{C}$ for air temperature. In daytime with intensive solar radiation and a high snow surface albedo (early in the observation period), the accuracy of the air-temperature measurements was, however, somewhat less, because the radiation shield did not fully protect the sensor from reflected solar radiation.

A precipitation gauge was installed on the ice (Finnish Precipitation Gauge, model H\&H-90, Finnish Meteorological Institute), and total precipitation was recorded daily. Cloudiness was recorded at least every second hour during daytime (usually 0600-2000 h), by the same person throughout the whole period to keep the observations consistent.

The global $\left(S_{\downarrow}\right)$ and reflected $\left(S_{\uparrow}\right)$ shortwave radiation were measured with upward- and downward-facing Eppley pyranometers (Model PSP), while the upward and downward longwave fluxes ( $L_{\uparrow}$ and $L_{\downarrow}$ ) were measured with downward- and upward-facing Eppley pyrgeometers (Model PIR). Measurements were made every $1 \mathrm{~min}$ and further averaged every $10 \mathrm{~min}$. All fluxes are defined positive 

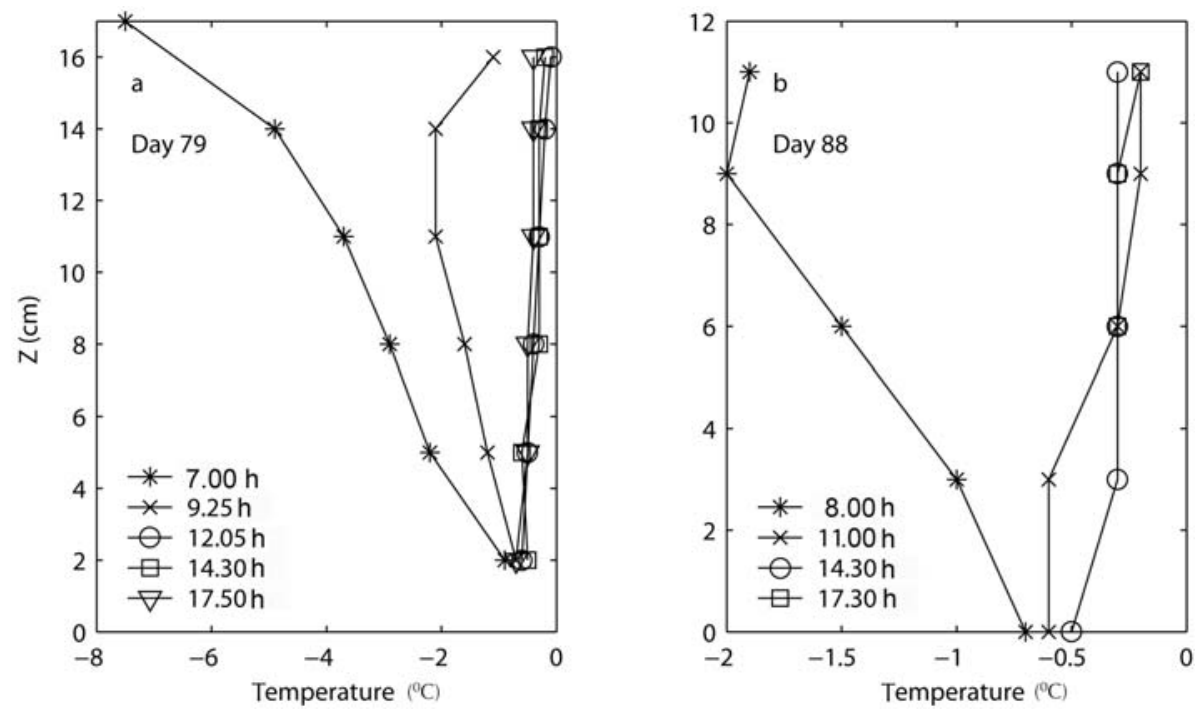

Fig. 2. Typical snow temperature profiles on (a) day 79 and (b) day 88 . The zero depth refers to the snow-ice interface.

towards the snow surface. The surface temperature $\left(T_{\mathrm{s}}\right)$ was solved from the recorded $L_{\uparrow}$ and $L_{\downarrow}$

$$
L_{\uparrow}=\varepsilon \sigma T_{\mathrm{s}}^{4}+(1-\varepsilon) L_{\downarrow}
$$

where $\sigma$ is the Stefan-Boltzmann constant and $\varepsilon$ is the surface emissivity; we used $\varepsilon=0.97$.

The domes of the radiation sensors were checked every morning and, when needed, cleaned of frost or water droplets. Also the horizontal leveling of the radiometers was checked and adjusted every morning. During daylight with $S_{\downarrow}>200 \mathrm{~W} \mathrm{~m}^{-2}$, we applied a more sophisticated empirical correction for the solar heating of the domes of pyrgeometers, while a simple setting of a threshold value at $0^{\circ} \mathrm{C}$ was applied when $S_{\downarrow}$ was $<200 \mathrm{~W} \mathrm{~m}^{-2}$.

The corrections were based on the fact that the snow surface temperature cannot exceed $0^{\circ} \mathrm{C}$, while the uncorrected data showed surface temperatures around $+2^{\circ} \mathrm{C}$ during melting conditions. After the correction, we estimated that the relative error remaining in the longwave radiation data is $1 \%$ during surface melting, $2 \%$ at nighttime in freezing conditions, and $5 \%$ in other cases. The errors in the longwave fluxes result in an absolute error in $T_{\mathrm{s}}$ of about $0.5^{\circ} \mathrm{C}$ during surface melting, $1-1.5^{\circ} \mathrm{C}$ at nighttime in freezing conditions, and $3^{\circ} \mathrm{C}$ in other cases. The error associated with the pyranometer measurements is about $5 \%$.

\subsection{Calculation of turbulent surface fluxes}

The turbulent fluxes of sensible heat $(H)$ and latent heat $(\lambda E$; $E$ is evaporation and $\lambda$ is the latent heat of vaporization) were derived from the observations using the bulk method:

$$
\begin{aligned}
H & =\rho C_{\mathrm{p}} C_{H E}\left(\theta_{\mathrm{a}}-\theta_{\mathrm{s}}\right) V \\
\lambda E & =\rho \lambda C_{H E}\left(q_{\mathrm{a}}-q_{\mathrm{s}}\right) V,
\end{aligned}
$$

where $\rho$ is the air density, $c_{\mathrm{p}}$ is the specific heat, $\theta$ is the potential temperature, $q$ is the specific humidity, and the subscripts a and $\mathrm{s}$ refer to the air ( $2 \mathrm{~m}$ height) and surface, respectively. The transfer coefficient $\left(C_{H E}\right)$ depends on the thermal stratification in the atmospheric surface layer and on the roughness lengths for momentum, heat and moisture. Under stable stratification, which prevailed during our study, we applied the functions of Holtslag and de Bruin (1988), recently recommended by Andreas (2002). We used the formula of Banke and others (1980) for the roughness length for momentum, and that of Andreas (1987) for those for heat and moisture. On the basis of comparisons between measured and parameterized turbulent fluxes (Launiainen and Vihma, 1990; Launiainen and others, 2001), we estimate that the accuracy of the fluxes was of the order of $\pm 20 \%$. Under very stable stratification during weak winds, the relative error may be larger. In such cases, however, the magnitudes of the fluxes were only a few $\mathrm{Wm}^{-2}$, and the absolute errors therefore remained small.

The net turbulent and radiative energy flux to the snow surface $\left(Q_{\text {net }}\right)$ was computed as

$$
Q_{\text {net }}=S_{\downarrow}+S_{\uparrow}+L_{\downarrow}+L_{\uparrow}+H+\lambda E .
$$

\section{RESULTS}

\subsection{Development of snow and ice properties}

The initial density of the snowpack was about $420 \pm$ $70 \mathrm{~kg} \mathrm{~m}^{-3}$ (day 78, average \pm standard deviation over entire snow depth). With an approximate thickness of $15 \mathrm{~cm}$ (days 76-78), it had a water equivalence of $63 \pm 10 \mathrm{~mm}$. However, the snow thickness varied considerably, with a minimum of $12 \mathrm{~cm}$ and a maximum of about $20 \mathrm{~cm}$ when the observations commenced. During the observation period, the snow density varied from 350 to $500 \mathrm{~kg} \mathrm{~m}^{-3}$, except for intermittent lower densities for fresh surface snow layers. These layers, however, rapidly compacted. The high snow density and the presence of a several $\mathrm{cm}$ thick ice layer on the snowpack at the beginning of the measurement period suggest that some melting events had already occurred before the observations commenced. Sometimes it was difficult to measure the snow density because of the presence of ice layers at the surface and very wet snow at the bottom of the snowpack. Because of these problems the snow density may be underestimated, because the densest layers were occasionally omitted. The snow cover developed a hard crust at nighttime that softened in the daytime. Diurnal variations in snow temperature (Fig. 2) and hardness were evident, especially during periods of clear sky or modest cloud amount. Ice lenses or coarse-grained icy layers were also often observed in the interior of the snowpack. 

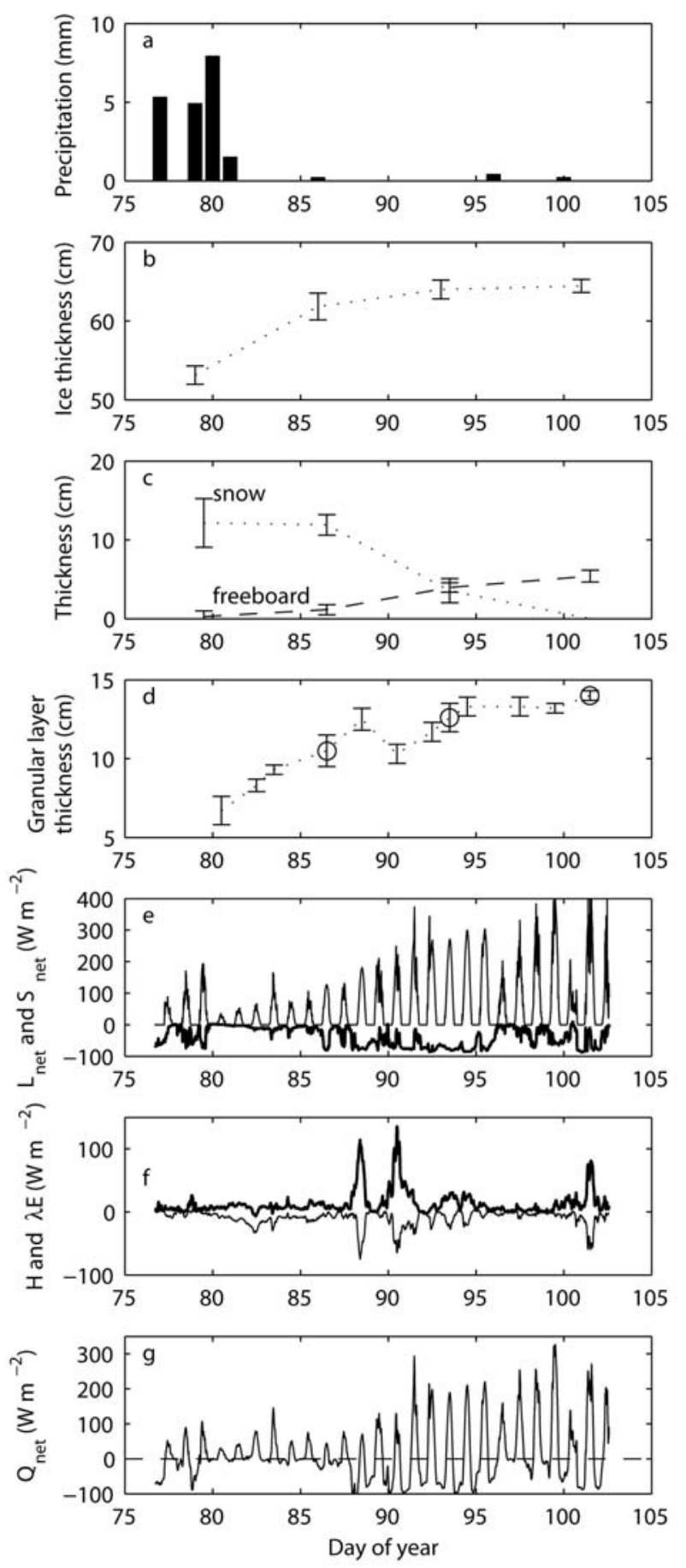

Fig. 3. (a) Precipitation; (b) ice thickness; (c) snow depth and ice freeboard; (d) surface granular ice layer thickness; (e) net shortwave radiation (thin line) and net longwave radiation (thick line); (f) fluxes of sensible heat (thick line) and latent heat (thin line); and (g) net turbulent and radiative heat flux at the snow surface. In (d) circles denote the results from the ten-core profiles, while the other results are from the three-core sets. Average and standard deviation are shown in $(\mathrm{a}-\mathrm{d})$, and a 1 hour moving average in $(\mathrm{e}-\mathrm{g})$.

Usually the snowpack appeared soaking wet at the ice-snow interface, especially during the late afternoon. It was often hard to distinguish the exact transition from snow to ice, so precise determination of the ice freeboard and upper ice surface was difficult. When coring, care was taken not to disturb the upper ice surface (i.e. the snow was not removed before coring), and the upper solid ice surface was used

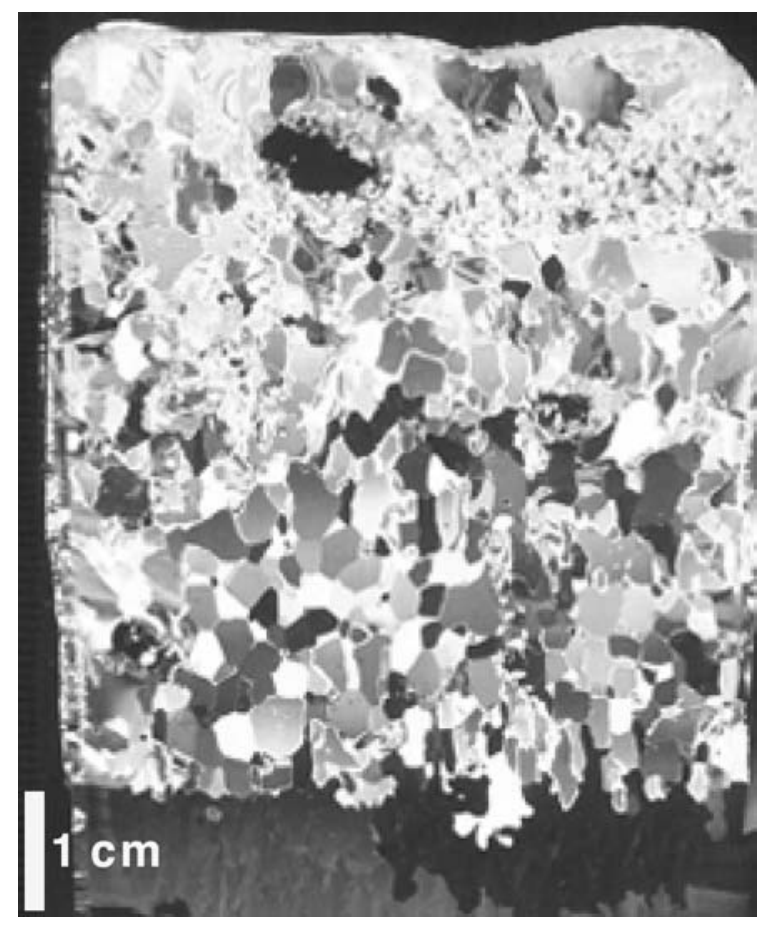

Fig. 4. Texture of the topmost $8 \mathrm{~cm}$ of an ice core taken on day 80 .

when estimating the freeboard and surface granular ice layer thickness.

The time series of observed precipitation, ice thickness, snow depth, ice freeboard and surface granular ice layer thickness are shown in Figure 3a-d. During the observation period, ice thickness and freeboard increased while snow thickness decreased consistently (Fig. 3b and c). During the first week, snow depth did not decrease, because melting was compensated by an accumulation of approximately $5 \mathrm{~cm}$ of new snow (Fig. $3 \mathrm{a}$ and $\mathrm{c}$ ). At the end of the experiment (day 100 onwards) no snow remained on the ice, except in some small whitish patches of icy grains. Precipitation during the period totaled $20 \mathrm{~mm}$, and the majority accumulated as snow before day 83 (Fig. 3a). Adding this to the initial snow mass, the snowpack on top of the ice amounted to $83 \pm 10 \mathrm{~mm}$ w.e. At the start of the experiment the ice had, on average, a slightly positive freeboard $(0.3 \pm 0.7 \mathrm{~cm})$. At the end of the experiment, when the ice was practically snow-free, the freeboard had increased on average to $5.5 \pm 0.8 \mathrm{~cm}$ (Fig. $3 \mathrm{~b}$ ).

\subsection{Observations on surface granular ice layer development}

The analyses of the surface ice structure development show there was a substantial increase in the thickness of a granular ice layer at the surface. From $6-7 \mathrm{~cm}$ thick at the start of the observation period (Fig. 4), it increased to a thickness of $14 \mathrm{~cm}$ at the end of the experiment (Fig. $3 \mathrm{~d}$ ). Both the threecore and ten-core datasets show the same general trend of increasing granular ice thickness (Fig. 3d). Hence, the observations suggest that during the observational period a $7-8 \mathrm{~cm}$ thick layer of granular ice was formed at the surface. Since the ice freeboard was positive throughout (Fig. 3c), except at the very beginning, snow-ice formation cannot explain the upward thickness growth.

The whole surface granular layer had very negative $\delta^{18} \mathrm{O}$ values, between $-10.7 \%$ and $-14.4 \%$ (Fig. 5), similar to or 


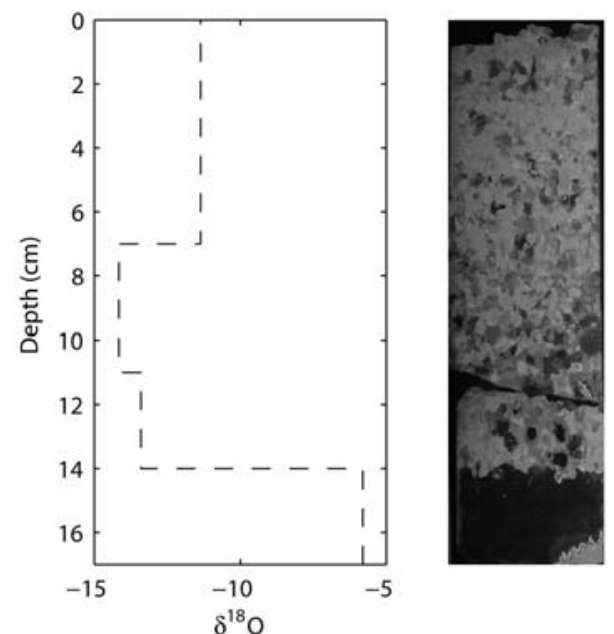

Fig. 5. $\delta^{18} \mathrm{O}$ profile and crystal structure of thick section of the topmost $17 \mathrm{~cm}$ of an ice core taken on day 97 .

lower than snow sampled in the area $(-11.2 \pm 1.3 \% ; n=9)$. The layer that formed during the experiment had a $\delta^{18} \mathrm{O}$ composition comparable to that of snow. This indicates that the granular ice layer that developed during the period was superimposed ice. The initial $7 \mathrm{~cm}$ thick granular layer, however, had $\delta^{18} \mathrm{O}$ values somewhat lower than those of snow. This suggests that it too was superimposed ice; seasonal variations in $\delta^{18} \mathrm{O}$ values in the precipitation over the study area, with lower values in winter, may account for the lower initial $\delta^{18} \mathrm{O}$ signal. The observed $\delta^{18} \mathrm{O}$ values for snow and the granular ice layers are in fair agreement with earlier observations for snow in the area (Granskog and others, 2003a). Beneath the granular layer was a $2-4 \mathrm{~cm}$ thick layer that appeared to consist of a single crystal; this ice below the granular layer generally had $\delta^{18} \mathrm{O}$ values of -6.3 to $-6.7 \%$, close to that of brackish water in the area $(-6.6 \%$; salinity around 4.1$)$. While the initial surface granular ice layer had a salinity of 0.0 , the layer formed during the experiment had a salinity $\leq 0.1$ (personal communication from M. Steffens, 2005). Salinities of congelation ice below the granular ice layer ranged from 0.5 to 0.8 , which is within the range observed earlier in the area (Granskog and others, 2003a). The salinity and isotopic $\left(\delta^{18} \mathrm{O}\right)$ composition of the ice point towards the conclusion that all of the $14 \mathrm{~cm}$ of granular ice on the surface was superimposed ice. This means that superimposed ice formation had contributed to $22 \%$ of the total ice thickness at the time all snow had disappeared.

Further support that the initial granular ice layer was superimposed ice is provided by the weather conditions prior to the experiment. Data from an automatic weather station, Valassaaret $\left(63.43^{\circ} \mathrm{N}, 21.07^{\circ} \mathrm{E} ; 62 \mathrm{~km}\right.$ from the measurement site), indicated that during the period 1 January-15 March 2004 the diurnal maximum air temperature exceeded $0^{\circ} \mathrm{C}$ on 27 days. This had most likely provided conditions for surface (snow) melt, which is a prerequisite for superimposed ice formation.

The superimposed ice layers formed during the observation period lacked the coarse-grained polygonal texture (Fig. 5) often assumed to be a characteristic feature of superimposed ice (e.g. Kawamura and others, 1997, 2004; Haas and others, 2001). The structure was more like that of
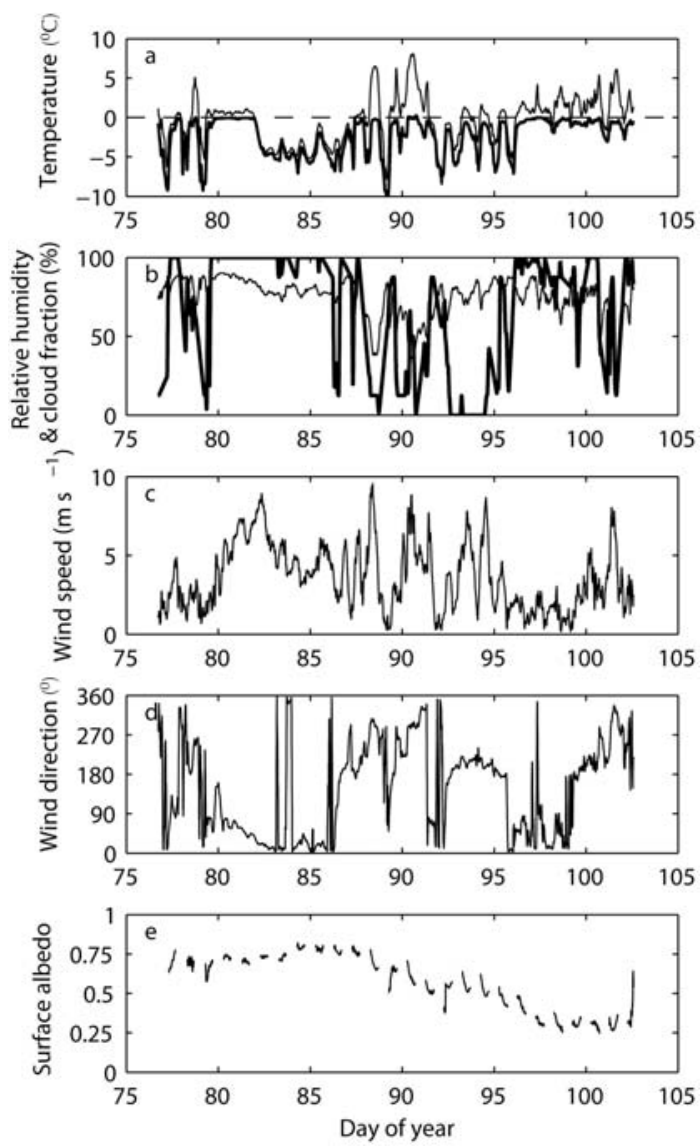

Fig. 6. Time series (1 hour moving average) of (a) $2 \mathrm{~m}$ air temperature (thin line) and surface temperature (thick line); (b) relative humidity (thin line) and cloud fraction (thick line); (c) wind speed; (d) wind direction; and (e) surface albedo (only calculated for solar height angles exceeding $10^{\circ}$ ).

snow ice with a rather fine-grained structure (see Fig. 5) or that of melt/freeze metamorphic snow observed by Nicolaus and others (2003, fig. 8). Although, at the start of the experiment, the existing granular ice layer had some polygonal texture (Fig. 4), the grain-sizes were overall $<0.5 \mathrm{~cm}$, considerably smaller than, for example, those of superimposed ice observed in the Ross Sea, Antarctica (Kawamura and others, 2004). Furthermore these layers appeared bubbly, unlike superimposed ice layers in the Antarctic (Kawamura and others, 2004; personal communication from C. Haas, 2005). At the end of the experiment, the texture of the newly formed granular layer resembles that of snow ice previously observed in the same area (Granskog and others, 2003a), while the initial layer still had some polygonal characteristics.

\subsection{Turbulent and radiative fluxes}

Here we focus on the observed meteorological boundary conditions, and use them as a basis to interpret the observed changes in snow and ice characteristics. The weather and radiative conditions during the observation period were variable (Figs $3 \mathrm{e}-\mathrm{f}$ and 6 ). Periods with above- and belowfreezing temperatures, high and low cloudiness, as well as high and low wind speeds, alternated frequently (Fig. 6). Due to the large solar radiation and occasionally high air temperatures, the $15 \mathrm{~cm}$ thick snow layer completely melted, although the mean values of both the snow-surface 
and $2 \mathrm{~m}$ air temperatures were below zero $\left(-2.5^{\circ} \mathrm{C}\right.$ and $-0.4^{\circ} \mathrm{C}$, respectively). On the basis of Equation (3), a total of $9 \mathrm{~mm}$ w.e. of snow sublimated during the observation period. The measurement period can be roughly divided into seven sub-periods characterized as follows:

\section{(a) 16-19 March (before noon) (days 76-79)}

During this period, winds were weak and the cloud cover variable. The air temperature had a large diurnal cycle, exceeding $0^{\circ} \mathrm{C}$ in the daytime and being $<0^{\circ} \mathrm{C}$ at nighttime. On 19 March, the snow temperature had a large diurnal cycle in the uppermost layers, reaching $0^{\circ} \mathrm{C}$ at the surface (Figs 2 and 6a). Although the air was much warmer than the snow surface, the turbulent fluxes remained small due to weak winds. The first systematic measurements of snow and ice thicknesses were made on 19 March (Fig. 3).

\section{(b) 19 March (afternoon)-21 March (days 79-81)}

Warm air originating from the south caused overcast conditions, and the air temperature continuously exceeded $0^{\circ} \mathrm{C}$, with a negligible diurnal cycle. Snow was melting at the surface, but we did not detect a decrease in the snow thickness, as the melt was compensated by wet snowfall. Due to the small air/surface temperature difference, the turbulent fluxes remained small (Fig. 3f) (the mean value for the sub-period was $8 \mathrm{~W} \mathrm{~m}^{-2}$ ). The net longwave radiation $\left(L_{\text {net }}=L_{\downarrow}+L_{\uparrow}\right)$ was negative or zero (mean value $-5 \mathrm{~W} \mathrm{~m}^{-2}$ ), and the net radiation was positive due to the net shortwave flux $\left(S_{\text {net }}=S_{\uparrow}+S_{\downarrow}\right.$; mean value $\left.16 \mathrm{~W} \mathrm{~m}^{-2}\right)$, which was the main factor melting the snow. A prerequisite for the melt was, however, the high air temperature. Because of the overcast sky and the relatively high surface albedo (around 0.70 ), the net shortwave flux was small, and would not have generated melting in different synoptic conditions (cf. subperiod (c)). Refreezing of the meltwater in the bottom of the snowpack was observed.

\section{(c) 22-26 March (days 82-86)}

The weather continued cloudy, but the wind turned to the north and the air temperature decreased to $-5^{\circ} \mathrm{C}$. The diurnal temperature cycle remained small (except on 25 March). Solar radiation was now larger than on 20 and 21 March, but did not cause melting since the air temperature was low. This was the period of most significant superimposed ice formation (see Fig. 3d), and a granular ice layer several centimeters thick was observed at the bottom of the snowpack after this period.

\section{(d) 27-31 March (days 87-91)}

The weather conditions were dominated by the Foehn effect, which was most pronounced on 28 and 30 March. During northwesterly winds the air had flowed over the Scandinavian mountain ridge and lost most of its moisture content on the up-slope path. Then it had warmed adiabatically on the downslope path. As a result, very warm and dry air was advected over the measurement site. Hence, a shallow, strong surface-based temperature inversion of up to $8.4^{\circ} \mathrm{C}$ in the lowest $2 \mathrm{~m}$ of the atmosphere was observed over the melting snow (Fig. 6a). The sensible-heat flux from air to snow reached a maximum of $150 \mathrm{~W} \mathrm{~m}^{-2}$, which would cause snowmelt of $4 \mathrm{~mm} \mathrm{a}^{-1}$ (for a snow density of $420 \mathrm{~kg} \mathrm{~m}^{-3}$ ). The air was very dry, however, so the latent-heat flux simultaneously had an upward direction. Part of the heat was therefore used for sublimation instead of melting. The cloud cover was variable, the sun was mostly visible and the air temperature had a large diurnal cycle and remained above $0^{\circ} \mathrm{C}$ during two nights. During this period, the surface albedo decreased from approximately 0.75 to 0.52 (Fig. 6e). The diurnal cycle of solar radiation increased, and at noon the net solar radiation reached or exceeded the sensible-heat flux. The net longwave radiation was, however, negative, and the net radiation averaged over the whole period was close to zero. Observations indicated that this was the period with most rapid snowmelt (Fig. 3c), which is in accordance with the observed decrease in surface albedo. At the beginning of the period, there was superimposed ice formation due to the strong diurnal temperature cycle, but later a decrease was observed in the granular ice thickness (Fig. 3d). The possible reasons are melting of the granular ice, horizontal variations in the snow and ice cover between the exact sites of successive observations, and the fact that in melting conditions it was hard to distinguish between snow and ice.

\section{(e) 1 April (day 92)}

A high-pressure system arrived from the north during the evening of 31 March, and was centered over the measurement site. The air temperature remained slightly below $0^{\circ} \mathrm{C}$ even around noon, when the net solar radiation reached a peak value of $340 \mathrm{~W} \mathrm{~m}^{-2}$. The surface temperature did not rise to the melting point, but remained above $-2{ }^{\circ} \mathrm{C}$ from 1000 to $1500 \mathrm{~h}$ solar time: in such conditions, subsurface melting is probable (Liston and others, 1999). Snow thickness decreased compared to the previous day, and superimposed ice was simultaneously formed due to refreezing at the icesnow interface and/or nighttime cooling (Fig. 3d).

\section{(f) 2-9 April (days 93-100)}

The snow thickness had decreased below $10 \mathrm{~cm}$, so the snow albedo strongly decreased, further decreasing snow thickness. Wind and cloud conditions were variable, but, partly due the decrease in surface albedo, solar radiation had become large enough to always cause a large diurnal cycle in the air temperature, which exceeded $0^{\circ} \mathrm{C}$ in the daytime and was $<0^{\circ} \mathrm{C}$ at nighttime. Snowmelt was observed in the daytime, but it was not as rapid as during sub-period (d), as the snow on the ice had already completely melted in many places. No further significant superimposed ice formation occurred, probably because of the reduced snowmelt and strongly reduced night-time refreezing in the latter part of the period, when the temperature remained relatively high because the sky was cloudy. Calculations based on Equation (3) suggest that $1 \mathrm{~mm}$ of meltwater evaporated during this period.

\section{(g) 10 April (day 101)}

Another Foehn event occurred, with turbulent fluxes, temperatures and air humidities comparable to those on 28 and 30 March. Snow disappeared completely, and the thickness of the superimposed ice layer reached its maximum. Although the layer thickness showed a $2 \mathrm{~cm}$ increase from 2 to 10 April (Fig. 3d), the total ice thickness remained practically constant (Fig. 3b). The probable reason is that some sea-ice melt occurred due to absorption of shortwave radiation. This is suggested by the fact that during the observation period the under-ice water salinity decreased from maximum values of about 4.5 to around 0.5 , indicating that some meltwater had accumulated at the ice-water interface. 


\subsection{Reasons for the refreezing of snowmelt}

Refreezing of the meltwater below or inside the snowpack requires a divergence of the net heat flux, which consists of the conductive heat flux and solar radiation penetrated into the snow and ice. The observations do not allow detailed analysis of the flux divergence, but, for the case of night-time refreezing at the ice-snow interface, we can roughly estimate the contribution to the refreezing by the cold ice below and the cold snow above the interface. The temperature at the ice bottom must have been close to the freezing point of $-0.3^{\circ} \mathrm{C}$ (for a water salinity of 4-5), while the temperature of the meltwater at the ice-snow interface must have been $0^{\circ} \mathrm{C}$. Assuming a heat conductivity of $2.1 \mathrm{~W} \mathrm{~m}^{-1} \mathrm{~K}^{-1}$ for the ice (Makshtas, 1991), we can calculate that in a steady-state condition with a linear temperature profile through $0.6 \mathrm{~m}$ thick ice, the conductive heat flux is only $1 \mathrm{~W} \mathrm{~m}^{-2}$. On the other hand, with a typical night-time snow surface temperature of $-5^{\circ} \mathrm{C}$ (Fig. 6a) and a heat conductivity of $0.3 \mathrm{~W} \mathrm{~m}^{-1} \mathrm{~K}^{-1}$ in the snow (Makshtas, 1991), the upward conductive heat flux through a $0.1 \mathrm{~m}$ thick snowpack is $15 \mathrm{~W} \mathrm{~m}^{-2}$.

The calculation presented is highly idealized, because steady-state conditions did not prevail at night, so the temperature profiles were not linear throughout the ice and snow layers. At the beginning of the refreezing period, the uppermost ice layers were probably colder than the ice bottom (as the typical night-time snow surface temperature was about $-5^{\circ} \mathrm{C}$ ). Hence, before a steady-state refreezing condition was reached, the conductive heat flux must have been $>1 \mathrm{~W} \mathrm{~m}^{-2}$. In any case, the upward $\left(15 \mathrm{~W} \mathrm{~m}^{-2}\right)$ and downward $\left(1 \mathrm{~W} \mathrm{~m}^{-2}\right)$ fluxes differ so much from each other that we can conclude that the cold snow surface temperatures at night and the longer cold periods (above all, subperiod (c)) were the primary reason for the refreezing.

Over the polar oceans in otherwise similar conditions, except that the ice bottom temperature is $-1.8^{\circ} \mathrm{C}$, the downward conductive heat flux would have been $6 \mathrm{~W} \mathrm{~m}^{-2}$, i.e. much closer to the upward flux. Nicolaus and others (2003) indeed observed that, in the Arctic, cold ice was essential for refreezing and superimposed ice formation.

\section{DISCUSSION AND CONCLUSIONS}

Our observations showed a gradual transformation of the snowpack, initially about $15 \mathrm{~cm}$ thick, into a superimposed ice layer about $7 \mathrm{~cm}$ thick, on top of the existing ice sheet during a 4 week period of spring melt-freeze. Some negative freeboards were observed only at the very beginning of the experiment, which leads to the conclusion that classical snow-ice formation did not contribute to the observed upward thickness increase during the study period. The isotopic composition and salinity of the granular ice layer also support this conclusion.

The upward growth of sea ice by about $7 \mathrm{~cm}, 64 \mathrm{~cm}$ in final thickness, corresponds to an $11 \%$ contribution to the total ice thickness after all snow had disappeared. Furthermore, before our observations began, a $7 \mathrm{~cm}$ granular ice layer already existed. The weather conditions favored superimposed ice formation, and the salinity and isotopic $\left(\delta^{18} \mathrm{O}\right)$ composition of the ice indicated it was superimposed ice. The total contribution of superimposed ice to the ice growth was thus $22 \%$ of the total ice thickness.

The mass of the initial snowpack should correspond to the mass of ice formed, unless there are mechanisms for loss of snow or snow meltwater. The initial snowpack $(15 \mathrm{~cm})$, together with the precipitation during the observation period, corresponds to $83 \pm 10 \mathrm{~mm}$ w.e. If we assume a superimposed ice density of $850 \mathrm{~kg} \mathrm{~m}^{-3}$ (Nicolaus and others, 2003), the initial snowpack would be transformed into a $97 \pm 12 \mathrm{~mm}$ thick ice layer. Our observations show the formation of a $70 \mathrm{~mm}$ thick superimposed ice layer. The difference might be explained by inaccurate density or thickness measurements, snow sublimation $(9 \mathrm{~mm}$ during the measurement period), lateral heterogeneity or perhaps some meltwater percolation into the underlying sea ice (Granskog and others, 2003b, 2004). Indeed, a study on meltwater percolation using a fluorescent tracer (rhodamine B) during the same period suggested that some of the surface meltwaters penetrated up to $30 \mathrm{~cm}$ depth from the surface from the start of the observation period to day 90, although the majority of meltwater was retained in the superimposed ice layers (M.A. Granskog and H. Kaartokallio, unpublished data).

Our findings suggest that knowledge of ice structure alone is not sufficient to distinguish between snow-ice and superimposed ice layers, and the low-salinity and $\delta^{18} \mathrm{O}$ signals are required to differentiate between them (Haas and others, 2001). The superimposed ice layers formed during our observations did not have characteristic polygonal grains, as often observed elsewhere. The texture observed here may be a result of the rapid transformation of snowmelt into ice at the bottom of the snowpack.

We have presented the first detailed study of superimposed ice formation during the entire snowmelt period in the Baltic Sea (except that melting had occasionally occurred during mid-winter), with detailed analyses of the atmospheric and solar radiative forcing. Due to the intensive solar radiation and occasionally high air temperatures, the $15 \mathrm{~cm}$ thick snow layer completely melted, although the mean values of the snow-surface and $2 \mathrm{~m}$ air temperatures were both below zero $\left(-2.5^{\circ} \mathrm{C}\right.$ and $-0.4^{\circ} \mathrm{C}$, respectively). The turbulent and radiative surface fluxes showed variations at seasonal, synoptic and diurnal timescales, which favored cyclic melting and refreezing and the growth of the superimposed ice layer. Together with the increasing solar elevation angle from a noon value of $26^{\circ}$ to a noon value of $36^{\circ}$, the decrease in surface albedo from 0.8 to 0.3 strongly increased the net solar radiation and the amplitude of its diurnal cycle. At the beginning of the campaign the solar flux contributed to melting only when conditions were overcast, when the net longwave flux was close to zero, while, in the second half of the experiment, melting also occurred during daylight when the net longwave flux was $<70 \mathrm{~W} \mathrm{~m}^{-2}$.

The turbulent fluxes were close to zero for most of the time, but the sensible-heat flux had a significant role in snowmelt during Foehn events, when dry, adiabatically warmed air masses were advected over the melting snow. Part of the heat was used for sublimation from the snow surface. Superimposed ice formation due to refreezing of meltwater occurred during most nights of the study period, and the most important refreezing periods were observed when the air and snow-surface temperatures remained below zero during daytime. This occurred during northerly winds (22-26 March) and under a high-pressure system (1 April). On 1 April, however, snowmelt was also observed, most probably in the form of subsurface melting caused by the large net solar radiation. 
Superimposed ice can form in the Arctic, Antarctic and the Baltic Sea, but there are important differences in the conditions controlling its formation. First, in the polar oceans, snowmelt takes place only during late spring and summer. Hence, superimposed ice usually does not contribute to the ice mass balance during winter, except for multi-year ice. In the Baltic Sea, however, snowmelt can take place at any time of the ice season; even during midwinter, warm-air advection can periodically result in above-zero air temperatures over the ice. Superimposed ice can therefore contribute to the ice mass balance throughout the ice season (Cheng and others, 2003; Granskog and others, 2004), which lasts approximately 6 months in the northernmost Baltic Sea. Second, although the Baltic Sea is located at lower latitudes, in the Arctic and Antarctic the incoming solar radiation is larger during mid-summer than during spring (March-April) in the Baltic Sea. Third, due to the lower salinity of the Baltic Sea, the ice bottom temperatures are higher. Hence, even under air temperatures as warm as approximately $-5^{\circ} \mathrm{C}$, the heat conduction towards the cold snow-air interface is the main factor for the refreezing of the meltwater. Under similar air temperatures in the polar oceans, the relative influence of the cold ice on the refreezing is larger than in the Baltic Sea. Hence, over multi-year ice in the polar oceans, we can expect that snowmelt is usually followed by superimposed ice formation, but in the Baltic Sea in spring, slush layers sometimes remain on the ice without refreezing.

Nicolaus and others (2003) observed an even more rapid growth of superimposed ice than we did: a $23 \mathrm{~cm}$ thick snowpack was transformed into superimposed ice in less than a week. In the case of Nicolaus and others (2003), the daily cumulative solar radiation at the top of the atmosphere (projected on a horizontal surface) and the surface albedo were larger than in our case, and the sky was overcast for most of the time after the onset of melt. The large incoming solar radiation together with the near-zero net longwave radiation (due to overcast conditions) provided a positive net heat flux at the snow surface for day and night after the melt onset. Hence, the continuous melting and the refreezing due to the cold ice below resulted in very rapid formation of superimposed ice. In our case, the process was slower due to the interrupted melting during most nights and a smaller heat sink in the ice below.

Although fast formation of superimposed ice was observed in our study and in Nicolaus and others (2003), superimposed ice can also form very slowly. During the Ice Station Polarstern (ISPOL) cruise in the Antarctic in summer 2004/05, snowmelt was extremely slow due to the very small heat fluxes into the snow (personal communication from C. Haas, 2005).

Hence, conditions for superimposed ice formation observed in some seasons in certain regions (e.g. the Baltic Sea, Svalbard or the Weddell Sea) cannot be generalized for other ice-covered oceans. On the other hand, although the meteorological conditions in the Baltic Sea have a large interannual variability, in each winter there are several alternating periods of snowmelt and refreezing, which provide prerequisites for superimposed ice formation. We therefore believe that superimposed ice formation is a recurring process in the Baltic Sea. It should also be taken into account in the coupled climate models developed in BALTEX.

\section{ACKNOWLEDGEMENTS}

The assistance of P. Kosloff, H. Kaartokallio, M. Steffens, J. Uusikivi and M. Molin in the field is greatly appreciated as is the help of the other participants in the experiment. The excellent facilities and technical assistance provided by UMSC made this work possible. E. Sonninen (Dating Laboratory, University of Helsinki) provided the oxygen isotope measurements. M.O. Jeffries, C. Haas and J. Hanesiak made constructive comments which led to improvements in the manuscript, as did the editorial aid of the Scientific Editor, M. Lange. The work was supported by a UMSC research grant and the Walter and Andrée de Nottbeck Foundation.

\section{REFERENCES}

Alexander, M.A., U.S. Bhatt, J. Walsh, M.S. Timlin, J.S. Miller and J.D. Scott. 2004. The atmospheric response to realistic Arctic sea ice anomalies in an AGCM during winter. J. Climate, 17, 890-905.

Andreas, E.L. 1987. A theory for the scalar roughness and the scalar transfer coefficients over snow and sea ice. Bound.-Lay. Meteorol., 38(1-2), 159-184.

Andreas, E.L. 2002. Parameterizing scalar transfer over snow and ice: a review. J. Hydrometeorol., 3(4), 417-432.

Banke, E.G., S.D. Smith and R.J. Anderson. 1980. Drag coefficient at AIDJEX from sonic anomometer measurements. In Pritchard, R.S., ed. Sea ice processes and models. Seattle, WA, University of Washington, 430-442.

Bengtsson, L., V.A. Semenov and O.M. Johannessen. 2004. The early twentieth-century warming in the Arctic - a possible mechanism. J. Climate, 17, 4045-4057.

Brümmer, B., A. Kirchgässner, G. Müller, D. Schröder, J. Launiainen and T. Vihma. 2002a. The BALTIMOS (BALTEX Integrated Model System) field experiments: a comprehensive atmospheric boundary layer data set for model validation over the open and ice-covered Baltic Sea. Boreal Env. Res., 7(4), 371-378.

Brümmer, B., D. Schröder, J. Launiainen, T. Vihma, A.-S. Smedman and M. Magnusson. 2002b. Temporal and spatial variability of surface fluxes over the ice edge zone in the northern Baltic Sea. J. Geophys. Res., 107(C8), 3096. (10.1029/2001JC000884.)

Cheng, B., J. Launiainen and T. Vihma. 2003. Modelling of superimposed ice formation and subsurface melting in the Baltic Sea. Geophysica, 39(1-2), 31-50.

Cheng, B., T. Vihma, R. Pirazzini and M.A. Granskog. In press. Modelling of superimposed ice formation during the spring snowmelt period in the Baltic Sea. Ann. Glaciol.

Granskog, M.A., T.A. Martma and R.A. Vaikmäe. 2003a. Development, structure and composition of land-fast sea ice in the northern Baltic Sea. J. Glaciol., 49(164), 139-148.

Granskog, M.A., H. Kaartokallio and K. Shirasawa. 2003b. Nutrient status of Baltic Sea ice - evidence for control by snow-ice formation, ice permeability and ice algae. J. Geophys. Res., 108(C8), 3253. (10.1029/2002JC001386.)

Granskog, M.A., M. Leppäranta, T. Kawamura, J. Ehn and K. Shirasawa. 2004. Seasonal development of the properties and composition of landfast sea ice in the Gulf of Finland, the Baltic Sea. J. Geophys. Res., 109(C2), C02020. (10.1029/ 2003JC001874.)

Granskog, M.A., H. Kaartokallio, H. Kuosa, D.N. Thomas, J. Ehn and E. Sonninen. 2005. Scales of horizontal patchiness in chlorophyll a, chemical and physical properties of landfast sea ice in the Gulf of Finland (Baltic Sea). Polar Biol., 28, 276-283.

Haas, C., D.N. Thomas and J. Bareiss. 2001. Surface properties and processes of perennial Antarctic sea ice in summer. J. Glaciol., 47(159), 613-625. 
Holtslag, A.A.M. and H.A.R. de Bruin. 1988. Applied modeling of the nighttime surface energy balance over land. J. Appl. Meteorol., 27(6), 689-704.

Jeffries, M.O., H.R. Krouse, B. Hurst-Cushing and T. Maksym. 2001. Snow-ice accretion and snow-cover depletion on Antarctic firstyear sea-ice floes. Ann. Glaciol., 33, 51-60.

Kawamura, T., K.I. Ohshima, T. Takizawa and S. Ushio. 1997. Physical, structural and isotopic characteristics and growth processes of fast sea ice in Lützow-Holm Bay, Antarctica. J. Geophys. Res., 102(C2), 3345-3355.

Kawamura, T. and 9 others. 2001. Time-series observations of the structure and properties of brackish ice in the Gulf of Finland. Ann. Glaciol., 33, 1-4.

Kawamura, T., M.O. Jeffries, J.L. Tison and H.R. Krouse. 2004. Superimposed ice formation in summer on Ross Sea pack ice floes. Ann. Glaciol., 39, 563-568.

Launiainen, J. and T. Vihma. 1990. Derivation of turbulent surface fluxes - an iterative flux-profile method allowing arbitrary observing heights. Environmental Software, 5, 113-124.
Launiainen, J., B. Cheng, J. Uotila and T. Vihma. 2001. Turbulent surface fluxes and air-ice coupling in Baltic Air-Sea-lce Study (BASIS). Ann. Glaciol., 33, 237-242.

Liston, G.E., J.G. Winther, O. Bruland, H. Elvehøy and K. Sand. 1999. Below-surface ice melt on the coastal Antarctic ice sheet. J. Glaciol., 45(150), 273-285.

Makshtas, A.P. 1991. The heat budget of the Arctic ice in the winter. Cambridge, International Glaciological Society.

Nicolaus, M., C. Haas and J. Bareiss. 2003. Observations of superimposed ice formation at melt-onset on fast ice on Kongsfjorden, Svalbard. Phys. Chem. Earth, 28(28-32), $1241-1248$

Onstott, R.G., T.C. Grenfell, C. Mätzler, C.A. Luther and E.A. Svendsen. 1987. Evolution of microwave sea ice signatures during early summer and midsummer in the marginal ice zone. J. Geophys. Res., 92(C7), 6825-6835.

Palosuo, E. 1963. The Gulf of Bothnia in winter. II. Freezing and ice forms. Merentutkismuslaitoksen Julkaisu/Havsforskningsinst. Skr., 209, 42-64.

MS received 12 May 2005 and accepted in revised form 1 December 2005 